\title{
7 Tradition-based Concepts of Death, Burial and Afterlife: A Case from Orthodox Setomaa, South-Eastern Estonia
}

\section{Introduction}

Interpreting the archaeological record is an eternal question for archaeology. One way to escape it is to remain limited by presenting data in a descriptive manner, but such an approach does not pave the way for deeper comprehension. To understand the record, different tools should be used for interpretations. Concerning burial archaeology of post-medieval times, ethnological and folkloric data can be of great value, especially if originating from a geographically and culturally close tradition-based context. If customs recorded in burial archaeology correspond to those known from folkloric or ethnological context, oral data can provide an extra dimension for understanding the former concepts of death and afterlife, also in reference to the spheres that are not reflected in the archaeological record at all, thus putting some flesh on the bones of burial archaeology.

The cultural convergence of Europe has unified the concepts of death and afterlife in two powerful waves. First, in the context of Christianization, and second in the frameworks of modernization and secularization, especially since the 20th century. As the result, earlier concepts of death and burial, those emerging with their roots from pre-Christian times, have disappeared or have been pushed to the fringes of memory. However, peripheral areas where cultural processes have been slower and old traditions had a longer persistence, sometimes enable the researchers to look into the past with death concepts totally different from both those of modern times, as well as of those of Christian character.

\subsection{Funeral Rites and Burial in Estonia - Archaeology, Folklore and Living Practices}

In the broader context of medieval and post-medieval Europe, the territory of Estonia, the northernmost of the three Baltic countries, was a periphery, both in geographic and cultural terms. The land, inhabited by people speaking not an Indo-European, but a Finnic language, was Christianized only in the early 13th century (1208-1227), in the course of the Baltic Crusades, and connected with the core areas of Europe up to the early 20th century only through the upper, German part of the society. In Estonia, because of the deep ethno-social conflict of the native population and the German-

(cc) BY-NC-ND $($ C) 2015 Heiki Valk

This work is licensed under the Creative Commons Attribution-NonCommercial-NoDerivs 3.0 License. 
speaking nobility, dual faith and syncretism of Christian and pre-Christian beliefs can be observed up to the 19th century (Valk, 2003). The old traditions survived long also in the field of burial customs whereby local village cemeteries, illegal in the Lutheran context, were broadly in use up to the 1720s (Valk, 2001, pp. 18-37). Village cemeteries of medieval and post-medieval times have often served as objects of archaeological research. Archaeological record from the churchyards ends even later. In the province of Livonia the practice of burial there was only prohibited in 1773 in the context of Enlightenment ideas (Hausmann, 1903, pp. 150-151). As the temporal gap between archaeology and folklore is rather short in Estonia, oral tradition offers here a good chance to interpret post-medieval and medieval burial rites and grave finds. Some aspects of burial customs, however, have much earlier origins.

The rural graves of Estonia from the Christian period contain several artefacts there exist numerous finds both from the village cemeteries and churchyards (Valk, 1995a, pp. 141-149; Valk, 2001, pp. 42-59, 72-78). In addition to simple jewellery and metal details of the costume, the dead were also furnished with real grave goods: coins, small tools and utensils. The latter include mostly knives and needles, but also whetstones and fire steels, in some cases also keys and remains of riding equipment were also present. In border areas the burial customs may have preserved a largely prehistoric, Late Iron Age character, including spears, axes and spurs as grave goods as late as the mid-15th century (Laul \& Valk, 2007).

Grave goods known from folkloric sources and ethnographic/ethnological practices of the 19th and 20th century - coins, minor tools and utensils - greatly resemble the archaeological record of the Christian period though the assemblage is even more rich, including objects of organic material which have mostly not been preserved in the archaeological record. The folklore records mention also body care items (hair brush or later comb, handkerchief, soap, bath/sauna whisk), pipe and tobacco, and sometimes also food. As a cultural innovation, quite frequently a bottle of vodka is noted. Folkloric data also contain numerous evidence about the purpose and meanings of the grave goods (Valk, 1995a, pp. 141-149; Valk, 2001, pp. 78-81). They are mainly considered to be necessary for the dead person on the way to the world beyond or in the afterlife, but also to ensure the wellbeing of the living and to avoid any harm that might come from the dead. Expressing social status and gender or age symbolism are of greatly less importance. The similarity of medieval and post-medieval grave goods to those known from the ethnological and folkloric data from the 19th and 20th century enables us to suppose also the continuity of beliefs. Most likely, folkloric information can retrospectively shed light also upon the meanings of grave goods and other burial practices in postmedieval and medieval times - the time gap between the abandonment of the village cemeteries and the beginning of folklore collections is limited to only four or five generations. Moreover, written data from the 17th and 18th century also gives evidence of similar beliefs as known from the oral or folkloric data of the 19 th and 20th century. 
The basis of Estonian traditional burial rites is the knowledge that death does not mean the end of life but it is just the transition of person and personhood into another form of existence and to other environments. The aim of the burial rites is partly to facilitate the transition of the person to the afterlife, and partly to protect the living from possible harm emerging from the loose soul or from the dead body. Many of the burial rites mean preparing the person for afterlife in the world beyond. As death may not always sever contact with the deceased the wishes of the dead person concerning the funeral must surely be followed.

\subsection{Setomaa -the Case Study}

An area where preconditions for preserving the old traditions have been especially favourable is the region of Setomaa on the borderlands of Estonia and Russia (Fig. 7.1) (Setomaa, 2014). This area is presently split between the two countries (since 1945), and populated partly by the indigenous Seto population, linguistically belonging to the southern Estonians, and partly by the Russians. Located immediately at the border of East and West, the small Seto community, numbering circa 8900 people in the mid-19th century and circa 13,600 in $1934^{1}$, lived on the fringes of both the Estonian and the Russian viewpoint for centuries - side by side with the Russians but still in different villages. Being separated from the Russians by the ethno-cultural and linguistic barrier, and from the Estonians by administrative border -the area belonged, unlike the rest of southern Estonia, not to the province of Livonia, but to the province of Pskov (i.e., to Russia) - the Seto culture functioned and developed largely in isolation, preserving a most archaic character as a whole.

Setomaa has been Orthodox and involved with the Russian state since its formation. The Christianization of the Setos occurred in different stages. Although burial rites give evidence of transition to Christian practices in the 11th century (Valk, 2009, pp. 165-167), intensive missionary activities were launched only in the mid-16th century by the Pechory (Petseri) monastery, founded in 1473 (Piho, 2011, pp. 15-16). Deeper Christianization of the Setos took place, however, as late as in the 19th century. When Estonia became independent after the collapse of the Russian Czar Empire in World War I, the Seto-populated border area of the Pskov Government with adjoining Russian territories was involved in the newly-born republic in 1920.

1 The present-day population in the Estonian part of Setomaa is ca. 3100 people (excluding the large diaspora, partly mixed with the Estonians; according to the census of 2011 ca. 12,549 people determined themselves as knowing the Seto language) and to this number some 300 people in its Russian part can be added. 


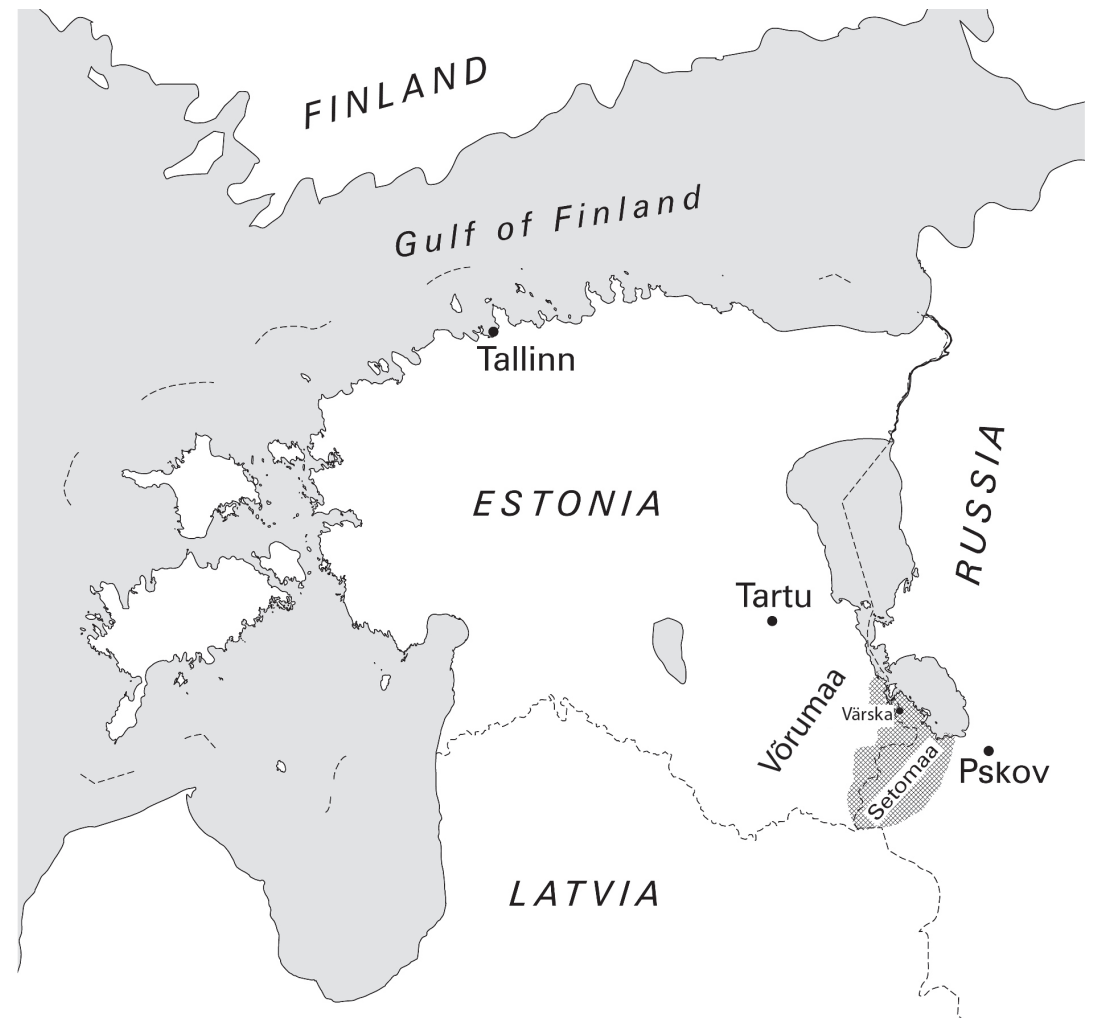

Figure 7.1: Location of Setomaa.

In the frameworks of Orthodox popular culture, several beliefs and practices of pre-Christian origin have survived long in Setomaa. Because of their long-term persistence, the local Russians called the Orthodox Setos 'half-believers' or 'halffaithful' (poluvercy). Archaic traditions survived also in the field of burial customs, afterlife and the meanings attributed to the cemetery. The Seto community lived in social, economic, religious and cultural terms a most archaic life until the 1920s when rapid modernization began. Since then the quick retreat of the old traditions started, hand-in-hand with the changes of generations. In spite of that, Setomaa enables us to have an insight into concepts of death and afterlife in the era of oral culture. Although originating from a definite spatial, temporal and cultural context, traditional Seto beliefs might nevertheless reflect some ideas and principles of more general character, enabling us to understand factors which have influenced the formation of the archaeological record and its diversity. When compared to the rest of Estonia, the burial traditions of Setomaa have preserved a more archaic and conservative character. In Setomaa, archaeological data from the village cemeteries go even up to the 1820 s. 
Likewise in adjacent Võrumaa district, grave goods belong also to present-day burial customs there. In addition, in the Orthodox cultural environment the ancient tradition of commemoration meals on the graves has preserved (Valk 2006). The burial rites of Setomaa (Arpo, 1996; Manninen, 1924; Richter, 1979, 1982) partly differ from those in Lutheran Estonia, having a large number of local variations. Differences may appear even between neighbouring villages.

This paper provides some reflections of my personal experiences from Setomaa, gained in communication with a person whose worldview greatly belonged to the time of her childhood - the 1910s and early 1920s. Its aim is to give an insight into some aspects of traditional Seto world view - those related to death, burial and afterlife. Unusual, strange and maybe even somewhat frightening, this knowledge might still be important for opening the meaning and backgrounds of burial rites and practices in the past. Although the examples presented below are just a cluster of diverse and occasional fragments, they hopefully give a survey of the concepts of death and afterlife in the traditional Seto mind, maybe necessary also for interpreting the archaeological record.

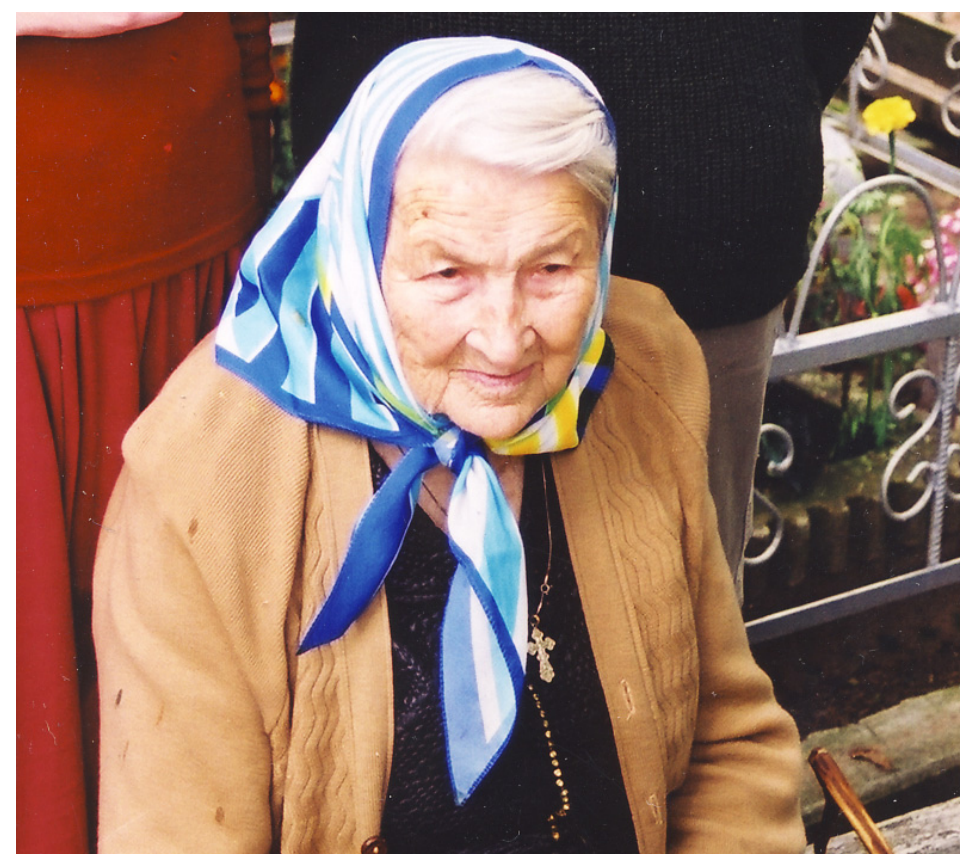

Figure 7.2: Mari (1912-2003) from Õrsava village in Setomaa, one of the last bearers of the traditionbased Seto popular religiosity, as it might have existed for centuries. This photo was taken on St Paraskeva's Day at the cemetery of Saatse. In ordinary time the neck cross was not worn on the clothes - the festive situation makes an exception. Photo: Author, July, 2000. 


\subsection{The Person and the Meetings}

The key person of this text is Maria (1912-2003), in everyday life just Mari (Fig. 7.2). She was born in small Õrsava village, $3 \mathrm{~km}$ from the church village of Värska, in a traditional peasant family where out of 14 children, six sisters and one brother lived to become adults. Mari lived the longest of them all. Many of Mari's beliefs, practices and knowledge came from her mother - a person of high authority both for the children and within the community. This woman, with some healing abilities, had helped in the births of more than 170 children. Having started working at a shop at Estonian army military camp in Värska, Mari got married at the age of 16 to the shop-owner, also of Seto origin. When business developed, they moved to inland Estonia in the 1930s, running a successful restaurant. The Soviet occupation put an end to their business and the family returned to the home village. In 1949, Mari's beloved husband was killed when returning from a fair at Pechory, having sold a cow there. There followed forced collectivization, loss of all her properties, unpaid work at collective farm and imprisonment, which forced the young widow with two children - two had died at a very young age - to leave for town. Time in Soviet prison gave an impetus for turning towards deep Christian religiosity, which had taken root during her childhood. Until retirement in the 1970s, Mari was a worker in the Pärnu fish industry, getting married once more. After having retired, she gradually returned to her home village, to the house bought by her sister - their own home had been lost. When the sister and her husband died, Mari inherited the place and lived there together with her son, also retired.

My meeting with her in May 1993 was fully accidental: an old woman raking the village street fascinated me with her stories about treasure-bearers and other amazing legends about the past and the supernatural. A year later, I visited her once more with some students. When the group was sitting on the grass, a small greyish blue butterfly whirled around us. Mari, noticing it, uttered as a comment: "Oh, it seems to be some soul, maybe of L. P.” and continued her stories. Traditional Seto knowledge about dead persons' souls visiting their homes as insects was not a legend any more, but a part of living reality. Since then I became a frequent guest in that house, often with students. News and new visits made me a welcome guest in the small household, and gradually I became like a member of the family.

In spite of increasing physical weakness, caused by old age, Mari had a very clear mind. Her wisdom and smartness were amazing. At the same time, she belonged to the persons who had returned, when getting old, to the spiritual realities that existed in the childhood - i.e. to the values and mentalities characteristic of the traditional Seto village of the early 20th century. During the last five to six years of her life, meeting the supernatural, and visitors from the worlds of death and afterlife, became a part of everyday reality for her; clear borders between the natural and transcendent often ceased to exist. Mari told me not only about memories from her time of youth, but opened also her own world of experiences, full of unexpected encounters with 
the supernatural. Here, in this small household, things known from old folklore collections often happened to be a part of reality.

The occasional bits of information gradually formed an integral whole which can never be gained when working in archives, with folklore notes collected in different times from different people in different places. My luck was to perceive it all in real life. Meeting Mari gave me a chance to meet another era - times when the natural was directly bound with that what is regarded as "supernatural" today.

This paper, that is based on notes from my visits to Õrsava village in 1993-2003, shares a part of experience gained from Mari - that concerning the fields of death, burial, cemetery and afterlife. The aim of the text is not only to open the popular meanings and hinterlands of burial practices, important also for interpreting the archaeological record, but also to mediate the perceptions of death and afterlife, as they existed in a cultural context characteristic of the era studied by archaeology - that of traditional oral culture. The text also shows how concepts and images of death and afterlife were formed, created and re-produced in that context. Mari's world view belonged to the other side of the large watershed of modernization. The era that she mentally represents might be characterised in cultural terms as representing the longue dureé of the Middle Ages.

Mari's world view is not a just personal case, but a representation of an old way of world perception and mentality, fragments of which can be found in different contexts in the Seto folklore collections. It belongs into the general context of popular Orthodox religiosity, characteristic also for other Finnic territories in the realm of Orthodox culture - the Karelian, Russian and Vepsian areas (e.g. Pentikäinen, 1971; Panchenko, 1998; Jetsu 2001; Stark 2002; Järvinen, 2004; Arukask 2012). Although encountering the supernatural, including communication with the dead in dreams, is a common part of the old Seto culture, it is hard to estimate how typical or untypical were perceptions of personal contacts with the dead in the real life of the past. These spheres are too intimate to be revealed to collectors of folklore, to alien and occasional guests in the household: there are several fields that are not open for the outsiders.

Hereby I express my deep gratitude to Mari for opening her world of beliefs, most necessary for understanding the past also on much broader scale. I am grateful to Mari for openness and kind permission to use my records and notes when she is gone - for people to know how it was in the past.

\subsection{Grave Goods, Clothing and Footwear}

Small grave goods are known in folkloric data in burial practices in all Estonia. In rural areas, grave goods are locally still remembered or being practised, especially in the countryside of its conservative south-eastern part and among the older generation. The body must be prepared for the afterlife, being furnished with the necessary small items, dressed according to the will of the person and having, obligatorily, footwear. 
According to fieldwork of 1998-1999, in three south-easternmost districts of Estonia grave gifts were quite frequent: $39.3 \%$ of respondents mentioned some favourite things of the dead person, $33.9 \%$ named coins and $23.2 \%$ specified a bottle of vodka laid in the coffin (Torp-Kõivupuu, 2003, pp. 126-132). In general, the items used as grave goods can be classified as liked by the deceased person or as his/her personal belongings (e.g. personal knife, toys for children, pipe) or objects closely bound to personhood (e.g. glasses, walking stick, personal tools, hearing-aid, bottle of vodka, cigarettes, work-related tool, etc.). Thereby, the wishes of the dead person are clearly of primary importance at making the set or selection. Moreover $74.1 \%$ of respondents claimed that the dead person is buried in clothes prepared by him/herself. Folkloric data include also some memories of burial in wedding costume, specially kept for that purpose.

Furnishing the dead with everything necessary to them was an important issue in old Seto burial practices (Arpo, 1996, pp. 256-260). So was it also in Mari's experience. According to her, money was laid in the coffin and the deceased was furnished with an Orthodox neck cross. A housewife was provided with some wool and woollen yarn - thus it is good for her to work there - and a man was given a knife, in addition to some money. A needle was put on the breast of the women - in the middle, to the right side, hidden under the clothes so that it could not be seen - to do some work there. Money was given because it might be necessary in the afterlife when going to the shop. Mari regarded giving money not as a magic practice but just as a custom, adding the explanation: "But everyone wants money in the grave. Money is said to be necessary there." The general explanation for items laid into the coffin was that "the dead person maybe needs to take it in the other world ... We do not know, how is life in the other world. Nobody knows." When one of my close old relatives died, Mari advised me to put a 1-kroon coin into the coffin - by the right elbow and ask for luck: "Luck is luck - either big or small."

Mari repeatedly remembered the death of her mother who died in 1949 and how she had prepared everything for that. Her mother was dressed in her wedding clothes, a white long coat, headcloth and headband - all home-made. Because of having helped to give birth to many children, she was buried with white gloves woven by herself - long, elbow-length and decorated with ornaments of white yarn. Mari's father was also buried in his wedding shirt: burying in wedding clothes was believed to be good for the deceased. In practice, this could be afforded only by richer people: the poor wore out their wedding clothes during their lifetime.

Mari said that it was not allowed to have any knots in the clothes of the dead and also the woven belt could not be tied - at Resurrection the dead must untie all the knots. Burial costume is important because the dead person will wear it in the afterlife. Mari had bought a new suit for her brother, but as he was deported to prison camp, it could not be used. When Mari's husband was killed, he was buried in the suit that was meant for her brother. Soon after her husband's burial, her brother appeared to Mari in dreams: "Dear sister, do not be displeased. I see how F. walks proudly with 
my suit, but I cannot get it.” Mari deeply regretted having dressed the body of her husband in her brother's suit.

Footwear is an important issue and Mari also asked to be buried in new shoes: "Then I can run and see my two husbands when they come to meet me." In the surroundings of Värska the shoes of the dead are not covered with the sheet/shroud in the coffin, but must remain uncovered. When Mari's older son was buried in the town of Pärnu, his shoes remained covered there. Soon after the funeral she dreamed of a monk, dressed in black, coming to take the son away from the grave: "Let us go now!” The son answered: "I cannot get my feet free.” Anyway, Mari was glad because his stay in the grave had been so short, even if he couldn't get his feet free at once.

Mari mentioned also other beliefs and customs related to burial. Concerning grave orientation, the direction that the dead person will be facing is important: in olden times the dead were buried facing the south, but now rather facing the church. She noted that when the dead body is in the house, mirrors are covered, silence is kept and the floor is not washed because the water goes upon the dead: the loose soul of the dead is believed to be close to the floor. However, having a running stream in the village makes a difference. Households on the other side of it do not need to avoid washing the floor.

In the Seto tradition the personal items of the dead remain unused during the 40 days when the soul of the dead person has not left yet. When Mari's older son died, his widow offered his clothes to Mari's other son, but Mari refused to take anything before that deadline.

\subsection{The Cemetery and Meals on the Graves}

In Seto tradition, the cemetery is a sacred area. The grave is not only the place for commemoration and mourning, but is primarily perceived as the location or dwellingsite of the departed. The cemetery is also an area for communication with those who have passed to the world beyond (Valk, 2006, pp. 143-144), especially during church holidays when the borders between the visible and invisible become more vague and open than usual: the intersection of sacred time and sacred space makes it possible for a while. The sacredness of the burial ground is reflected also in Estonian folkloric data about the village cemeteries, deserted in the first half of the 18th century (Valk, 1995b, pp. 505-506).

In the burial rites of south-eastern Estonia, food is of great importance (TorpKõivupuu, 2003, pp. 66-90). In earlier times, slaughtering an animal, or at least a chicken was obligatory for funerals. In Setomaa the archaic practice of having meals on the graves continues to the present day (Valk, 2001, pp. 81-83; Valk, 2006, pp. 141-144). Unlike the Catholic and Lutheran confessions, the Orthodox Church has been tolerant towards it. Food is served during the funeral on the freshly-closed grave and later at home, on personal commemoration days, including the commemoration 
of 40 days $^{2}$ (Fig. 7.3) and one year after the death, as well as on big church holidays. In earlier times, this practice was followed also on ordinary holidays and Sundays, after the sermon. When coming and leaving, some alcohol must be poured to the cross and, according to the tradition, some food was left on the grave or buried in the sand. Ritual consumption of food and alcohol is a means to facilitate communication - both among the living and between the living and the departed.

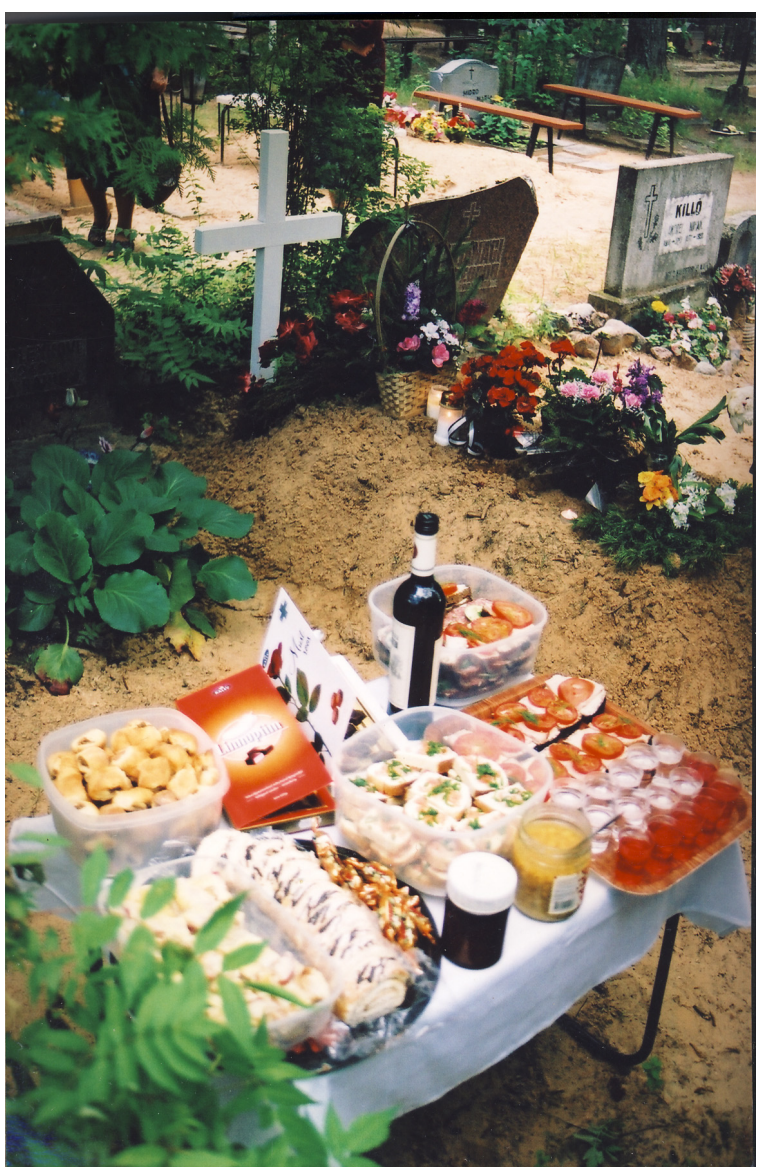

Figure 7.3: Mari's grave, Värska Cemetery on the commemoration day of 40 days after the death when the soul is seen off. In addition to sandwiches, cakes, sweets and cookiesthe traditional ritual burial food kutja, made of peas and honey, is on the table in an open jar. Photo: Author, June, 2003.

2 According to the Orthodox tradition the soul of the dead person is believed to stay in this world for forty days. Then, as the Seto say, it is 'set to its place'. 
In Lutheran Estonia only faint traces of the custom can be observed in folkloric collections and popular practices - they are preserved best in Võrumaa where food and drinks are still given to people after the funerals, outside the graveyard gates. However, materials of the Provincial Council of medieval Livonia ${ }^{3}$ from 1428 show that meals on the graves and even in consecrated churchyards was a serious problem of general character for the Catholic Church in medieval times (LUB VII, 690, p. 19).

The traditional belief that the location of the dead in afterlife is bound with the grave appeared also in my communication with Mari. Visiting the graves on holidays was most important to her. Mari taught me that alcohol must be poured on the grave first, before drinking yourself - not upon the cross but at its foot. However, thereby you must take the first drop and only then pour the drink - otherwise the dead cannot get it. She also told me that leaving pieces of cake on the grave stone is not correct: the soul comes to look for food on the ground surface. Once she expressed the wish of the dead: something, a piece of bread if nothing else, must always be left on the grave - then "we can take it from there."

Bringing food to the grave is not only a symbolic act. The custom must be observed, otherwise unwanted events may follow. In 1997 Mari said that for the Day of Transformation (August 19) she had promised to take a cock to her husband's grave: "I shall kill it and make a soup. We shall eat the soup ourselves, and the meat will be taken to the church, to the grave." Being sorry for the bird, she, however, did not fulfil the promise. When seeing a hawk making circles above her house some days later she was worried about the chicken: "The hawk knows that the cock was promised to F. Now he will come and take it."

On the Day of Annunciation, March 25, according to old tradition, people gathered on the graves, put candles there, ate pike, and some vodka was poured for the dead. However, Mari's son who was sent to the cemetery of Värska (Fig. 7.4) did not visit all the graves in 1998. The next day a fox came and took some chickens. As there had been no bad luck with fowls in the household before, the reason was clear. In addition, Mari later informed me how her sister with her husband, both deceased, appeared. The sister told it was her husband who took the hen and the cock - because no candle was put on their grave and no drink was poured there. And also during the Easter of 2001 when no egg was brought to Mari's parents' grave, and two pinkish red Easter eggs got broken at home, the reason for that was evident: "Yes, they took their share.”

3 The Provincial Council was the highest ecclesiastical institution of collective character in medieval Livonia. 


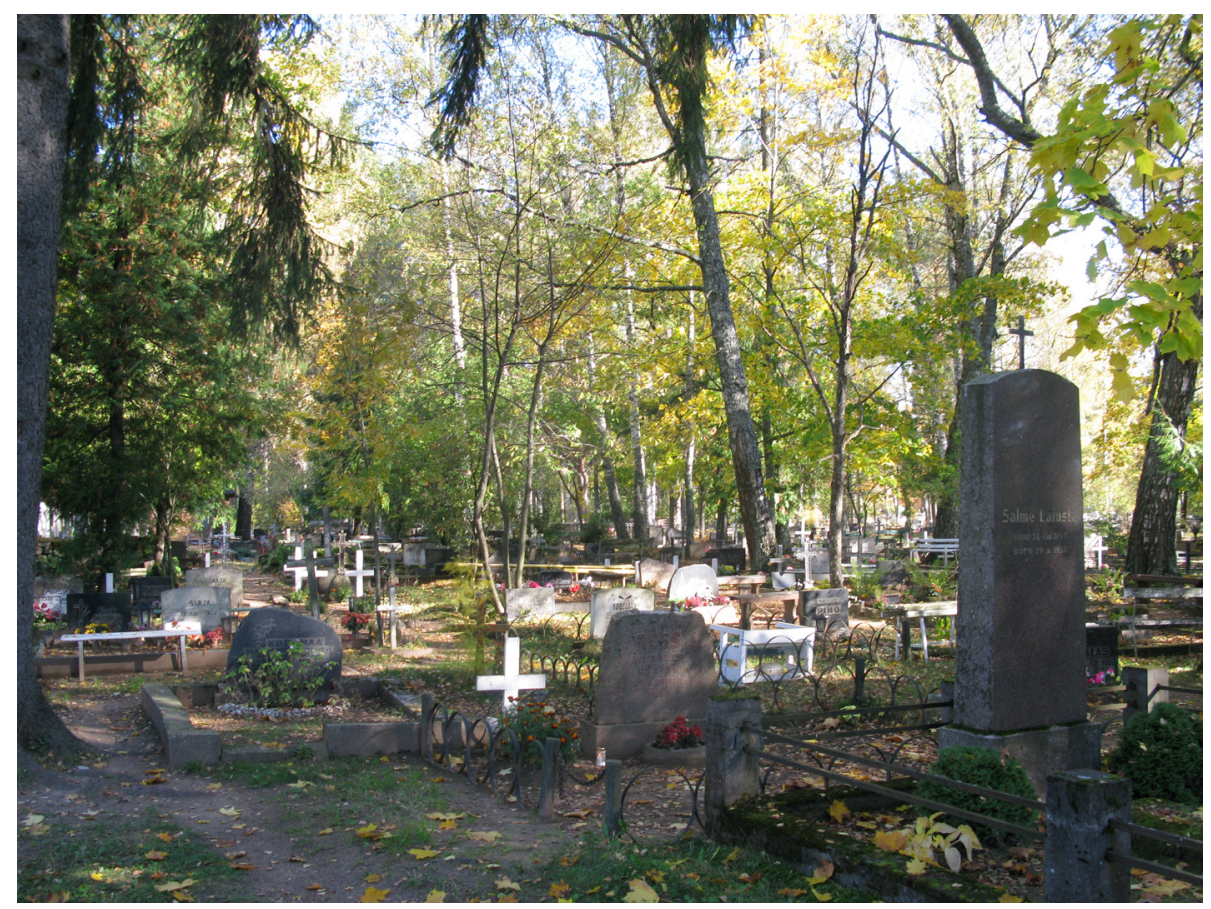

Figure 7.4: The cemetery of Värska. Estonian and Seto cemeteries are always covered with trees and have a forest-like atmosphere. In the old Seto tradition a tree growing on or at the grave was also the personification of the deceased buried there. Later this meaning was transferred to the grave cross that was touched with the hand when arriving and leaving. Timber crosses stand on the graves until they rot, and are not replaced. From graves designated with only a gravestone the crosses have disappeared already. Photo: Author, 2010.

The grave is also the area where things can be delivered to the dead. If something that should have been laid in the coffin has been forgotten, it can be added later, burying it in the grave. This belief and practise is known also in Võrumaa. In 2001 Mari discovered that the skirt of a recently dead relative which had remained in her household had got worms in it. She asked for it to be burned or taken to the cemetery. Since the person was buried in Tartu, at the grave of her father, and as the relatives probably would not have liked it, the first option was chosen. Mari also reminded me of a case when a nice shop candle was brought to the grave, but the dead person appeared in a dream and told that there was no use for it: the dead need candles from the church. 


\subsection{Meeting the Departed}

In the traditional Seto world view the dead continue their existence in an afterlife, separate from the world of the living. Information from there can occasionally appear in different ways, on different levels and through different channels. Messages from the dead and about their life 'over there' come, as we have already seen in case of Mari, most often via dreams.

In addition, in Mari's life another unexpected way of communication was opened: the dead started visiting her at home. During the last six years of her life, she repeatedly told about such meetings in her house (Fig. 7.5) and in her room, fully contradicting the materialistic concepts of reality. Meeting her dead relatives sisters with their husbands, parents and brother began in 1997, when Mari was 87. The experience was first somewhat frightening: "You see, the dead come welcoming me behind the window. Shall I die soon?”

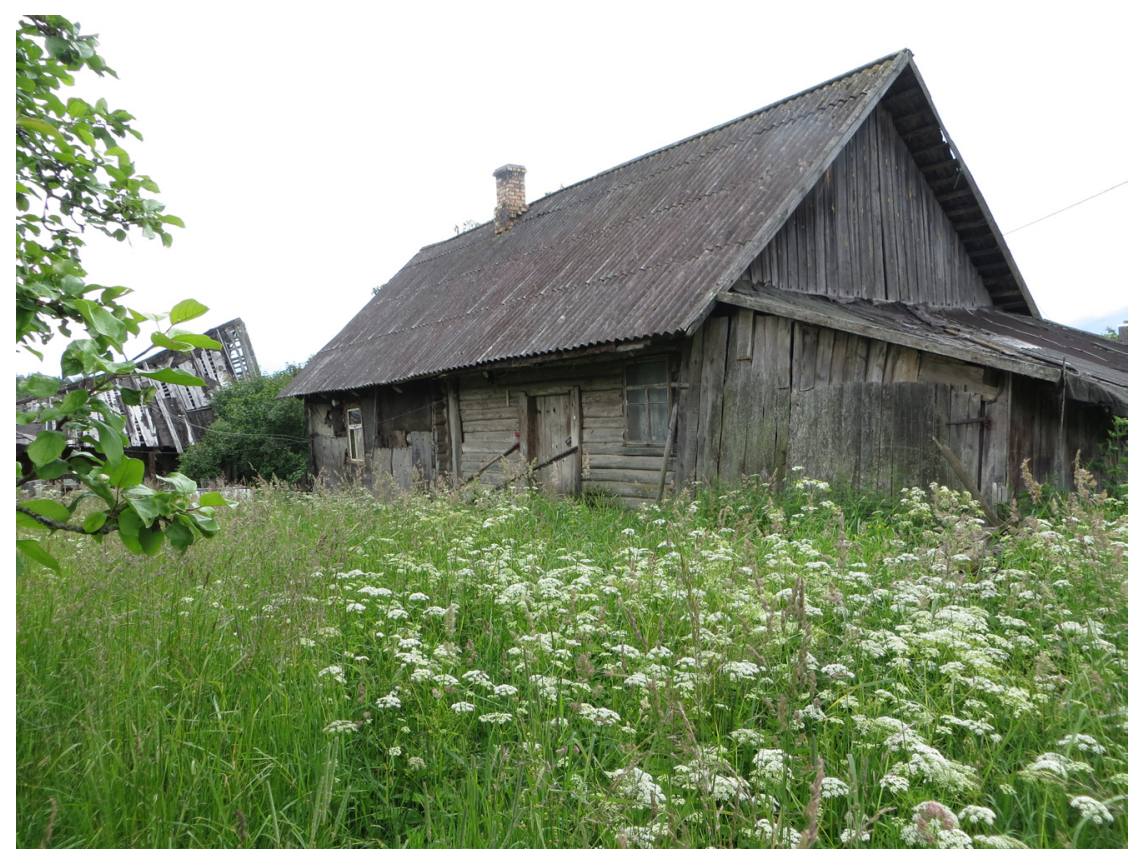

Figure 7.5: Mari's house in Õrsava village in Setomaa - a place where the supernatural could often be experienced. Since the death of Mari and her son the house has been empty for over six years. Photo: Author, June, 2014. 
However, the dead became quite frequent and lately even eagerly expected guests in Mari's life. They appeared unexpectedly, mostly in the clothes in which they had been buried, as old as at the age of death and with their faces unchanged. Once Mari had suggested her sister might stay the night, but she answered that the dead cannot sleep there but must get back to the cemetery. Mari's response to my asking how often the dead can visit the world of the living was: "Only when they are allowed. It is not so that they go whenever and wherever they want. They can leave [their place] for as much as they have earned. If they pray and behave well, they are released. They have order there. It is not so that they go when they want.” Talks during these visits greatly influenced and formed Mari's concept and knowledge of the life beyond.

A case when all the sisters with their husbands had visited her included a common meal in the small room. The dead appeared at once, as if from under the floor: "We came to see what are you doing here alone". One of the sisters asked: "Dear sister, please, pour for us, we cannot do it ourselves!" When they gave back the tiny glass cup, it was empty. The dead had their own food with them - somewhat similar to church bread given to people at Orthodox sermons. When Mari tasted it, a sister asked her not to bite this much: "This is our food share for the whole month. We are only licking - we cannot bite”. In response to my question about bodily communication, Mari told me that once she gave her hand to her brother. It felt somewhat like a hand but then her eyes opened and her hand was empty.

The brother who had died in Soviet prison camp in Vorkuta came once in the daytime, being as young as when deported in the late 1940s. He said he was sentenced to prison for his lifetime, but now when the time meant for living was over, he could leave the place. He wondered that nothing had remained from their home in Orsava village and complained about having no grave. When Mari replied that there was a grave for him in the churchyard - with a cross and text on the gravestone (Fig. 7.6), the brother disappeared - "probably to the cemetery"- and did not return any more.

The souls of the dead often appeared also as another form of being. A big butterfly at the window was supposed to be the soul of the deceased son and no moth was killed in the house because "it may be some soul." After the death of the older son - this hard and most painful blow happened in 1998 - Mari even did not kill flies: "maybe his soul is among them?" Strange flies which had lived in the room for the whole winter of 2001/2002 were also considered to be spirits: "I have counted, they are as many as we have dead [people] here. The masters have come home!” Meeting the souls incarnated as insects (Loorits, 1949, pp. 292-293) is common in Seto tradition, but souls may also appear in the shape of birds. 


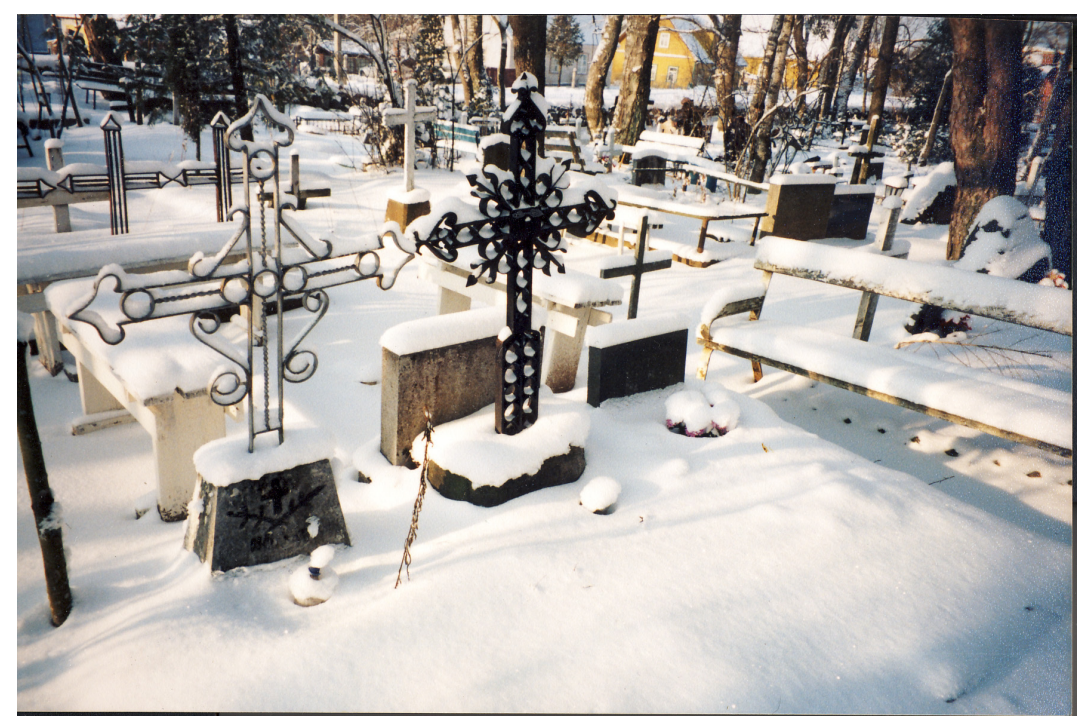

Figure 7.6: The grave of Mari's grandfather and parents. The black gravestone with the thin cross behind it is a cenotaph for Mari's brother who died in a Soviet prison camp in Vorkuta. Photo: Author, 2000.

\subsection{The World Beyond}

Popular images of afterlife correspond to the dualistic concept of 'good place' and 'evil place' characteristic of the old Seto culture. Mari's knowledge of the world beyond was based firstly on dreams, then on communication with the visiting dead and, finally, on personal experiences. In late 2001 she first told me about visiting Heavens. Two sisters came suddenly when she was sitting on the bed, took her by the elbows and then they went. There were many people in the State of Heavens (taevariik), all relatives. "I cannot tell you how is it there. All is different there... I would never have imagined that I can see Heaven in my bodily shape.” Heaven was a most important topic during the last year of life: "I see it very often, nothing else than it." Her reply to my question, if she had seen Heaven in reality or in a dream, was: "I do not know. And what is the difference?" Mari described the Paradise as a definite place in the Heavens - like a summer house with a nice garden where people go for vacation.

The key topic in terms of afterlife was news about the two closest people - her beloved first husband, and the older son who died in 1998. There was no information about the husband for a long time - those who die a violent death are separated from others, in another place, and cannot meet. Only meeting the dead relatives revealed that her husband was a superior person in Heaven and had two servants who made food for him - daughters of Mari's sisters. Old people had told her already 
that those who have been killed become superior. The dead sisters informed Mari that he lives well, although he has become older - living as if he were in a trough and waiting for her. In another dream Mari asked if she can meet her husband. The answer was that is up to him to decide - if he wants, they can meet. When being called, you must go at once: "If my son calls me, I must go to live with him, but if my husband - then to him." Messages from the life beyond convinced Mari that her dead son continued his work there - an assistant of Christ at judgement over the souls. He was assisted by two brothers who had died very young, and had grown only a little older.

From one of the dead sisters Mari heard also about other relatives: she had met some of them but some were in another place. There were only people from the surrounding villages in Heaven, and no unknown people. Only one person, suspected to be involved in killing Mari's husband, was missing: he is not in Heaven.

In popular perception the world beyond is not a real paradise. Life in Heaven may resemble ordinary life, also in practical terms. A dead sister told Mari that her [Mari's] son lived together with his father, in room No. 6, but she herself was in the adjacent room - No. 7. The husband had asked Mari not to be buried in white clothes - they would get dirty. This made her worried: all the dead whom she had seen in Heaven were dressed in white, or at least, in light-coloured dress. Mari told me that if clothes get worn, new ones will be given - you are not kept there without clothing.

In Seto popular images, the afterlife is not a place of active communication and the dead are somehow separated from each other: this appears clearly in dreams about the afterlife, including in the case of Mari. Men and women cannot meet there: although they are first together, they are later separated. When one of her sisters was killed by lightening, their dead father appeared to Mari in a dream in some festive hall, telling her that her sister had also come there. In response to her question about the sister, Mari saw her in the hall, somehow alone. And "that one, who leads the party, who shows the seats" went first and showed the sister a place to sit. Father told Mari: "we see all who come here but we cannot meet. Who comes, sits on the bench and we cannot meet.” The next day the telegram with the news of her sister's death arrived.

In another dream Mari visited one of her sisters in Heaven. The sister lived in a hall, like an old log house, with a door covered with a curtain. Three other people, all likewise ill, lay in one bed and the sister was opposite to them in the room. A woman, St Mary (Püha Maarja) stood at the door and did not want to let Mari in, but she still managed. When Mari lay on her sister's bed, they could talk but after the conversation the sister urged her to leave quickly: "if you stay until counting begins, the doors will be closed and you must stay here inside!” When leaving, St Mary was standing on the door, blocking her way out. After some struggle she managed to escape, but the shawl of a living sister, which Mari happened to have with her, fell down and remained in the house. Soon the news of that sister's death arrived. 


\subsection{Factors Forming the Afterlife}

In Seto beliefs the location and status of the dead in the world beyond depend on several factors - the age, time and manner of death, but also the way of earthly life: it is determined or sentenced for everybody "as you have earned". All this was communicated by Mari. She was somewhat worried about her future: those who get to Heaven while young have a good life there, but the life of the old will be miserable. It is good to die between Easter and Whitsun, when the gates of the Heavens are open and the souls can enter directly, but those dying after Whitsun must wait until the next Easter.

As mentined above, people who die a violent death, likewise those killed in a battle, are separated from others. In addition to her husband, this fate was shared by the daughter of Mari's sister, who had also been murdered. Mari told me she had a good job in Heaven, working as a cook and making food for others. In her free time she lived in a rose garden, among flowers, quite alone, and most satisfied with her life. The soul of the hanged or drowned must, however, stay in the place of death until the next person dies the same death there: only then it can leave: "If someone is drowned, he cannot escape the water spirits, until there is another in his place." In 1994 a man drowned in Lake Orrsava, after a long time. Mari said that the old people had discussed already why Nikolai who drowned there previously, in the 1950s, must have been in the water for so long $^{4}$.

Also all those who die without the presence of others are at first separated from others and only when their time is over, are they allowed to enter the Paradise garden - a beautiful place with flowers. When visiting her dead sister in Heaven in a dream, Mari had seen a crowd of young boys running in the corridor. These were the souls of those who had died alone, just released from the status of being separated. The wall opened and they could enter.

Afterlife may also be a punishment: the husband of one of the sisters was not allowed to meet others because he had killed three people in the war. The world beyond is hard for those who die of alcohol: they have no place in Heaven. Mari told me also about a new group who had visited her in her room - small children, homeless and who had frozen to death in the street. Small, miserable and some having the marks of freezing on the body, they wanted sweets and Mari was very sorry that she had none at home.

\footnotetext{
4 A similar explanation came to my question concerning the ferry Estonia which sunk on the Baltic Sea on September 28 1994, with 852 people drowned: "You see, many ships have sunk. This ship is not the first. But they went to save others. Those, who had drowned before, had their time full. And after that - again - how long time is written for them? Yes, those can, if someone drowns again, can go away - to the Heaven or where the souls go." My question if those who sunk together with the ferry went to release all the souls in Baltic Sea - got no definite answer: "I do not know. It is up to the water spirits."
} 
One of Mari's sisters who lived in Heaven in a room under the stairs had a hard time: she was permanently hungry and had only rye grains to eat. Mari told her that she commemorates her in the church (Fig. 7.7) and takes her everything but the sister answered that she gets none of it: the dead can eat only what they have given to others during their lifetime. She had been a stingy person.

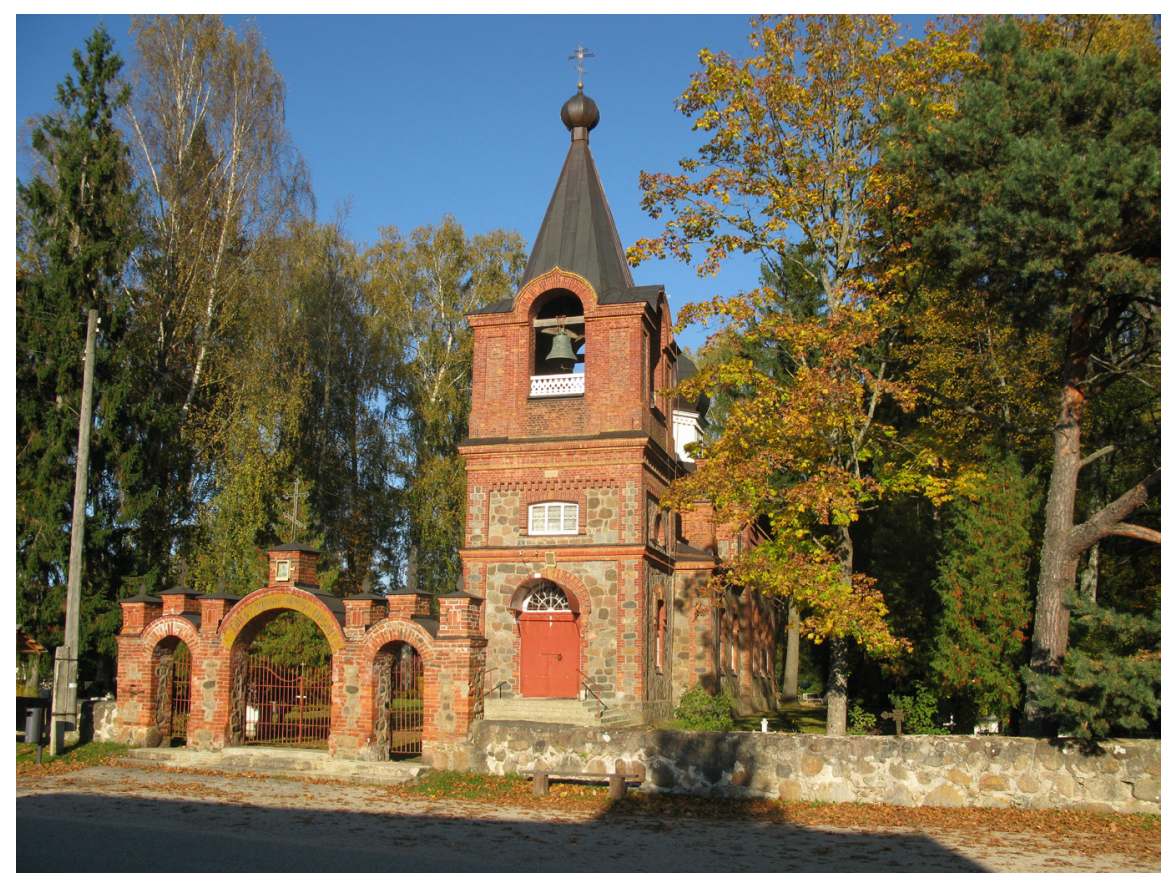

Figure 7.7: The Orthodox Church in Värska, built in 1904-1907, replacing the old timber church. The graveyard was established here only together with the new church. Earlier the dead were buried in the local village cemetery of medieval origin. Photo: Author, 2010.

\subsection{Discussion and Conclusions}

Beliefs are bound both with the individual and the society, being composed of several factors. The cultural traditions of the region or community form the background and backbone of individual world views. The second, family level provides the individual with information coming from the circle of closest relatives. Thirdly, personal experiences also contribute to the formation of personal beliefs and world views. All these factors had their role also in the formation of Mari's images of the world beyond.

The world has changed fast and it seems to be impossible any more to find people who live, on the basis of continuity, in the world of tradition-based oral culture in 
present-day Estonia. I am happy to have met Mari in Õrsava village and for the chance to encounter the living past. Although the contents of this chapter are based on communication with one person in one specific village, they surely have much broader backgrounds, representing concepts of death and afterlife characteristic of the old oral, pre-modern Seto culture (see: Valk \& Västrik, 1996, pp. 217-267). Fragments of similar perceptions can often be found in folklore collections as well as when talking to old people in any part of Setomaa.

As we saw above, many impulses for the formation of beliefs and ideas about death and afterlife may originate from dreams of the mourners and relatives, appearing either occasionally or after death and funerals. Although appearing at the personal level, this kind of information about the departed, as extraordinary and important, quickly spreads among the family, relatives and local community. Moreover, the border between natural and supernatural can be vague in traditional world perception. It often remains unclear whether connections between events are just a coincidence or something else - bound by intangible ties. In any case, the personal experiences of the 'supernatural' - either coming from dreams or real life - are most important factors to confirm, re-produce and develop beliefs provided by formerly existing cultural tradition.

The examples presented above also give some idea about the complexity of the perceptions of death and afterlife in a tradition-based society. Mari's beliefs represent a world view with concepts of death and afterlife totally different from ours. Death means transition, and the living can help somewhat to shape the fate of the deceased through burial rites and commemoration. The worlds of the dead and of the living are not fully separate and meetings are possible - through dreams and visions, and through communication in the sacred space of the cemetery, especially in the sacred time of holidays.

These fragments concerning afterlife in the Seto tradition enable us to suggest it to be rather similar to life on the earth. The dead need personal items, money and clothes, they work and may suffer hunger. Clothes get worn and dirty. The fact that the dead appear in dreams in the costume in which they were buried gives evidence of the meaning of burial costume. As in this world, the dead form a community based on kinship and neighbourhood, but people get older more slowly than in ordinary life. Although the image of afterlife is influenced by the Christian concept of Heaven. The State of Heaven is not a paradise, but a locus with problems and also with social inequalities. Christian ideas are mostly expressed in the images of afterlife only indirectly, on a meta level - in the perception that the dead are subordinated to anonymous powers, that they are no longer independent actors, and that there is Judgement by Christ on the other side. It is noteworthy that similar conclusions can be drawn also on the basis of the character of the archaeological record from the 13th - 17th centuries (Valk, 1995a, p. 150). However, only a small part of the diversity of beliefs can be reflected in the archaeological record: most of it exists and is preserved in the living mind and oral tradition. All in all, the Seto experience shows 
that in the popular form of Christianity concepts of death and afterlife can be diverse and manifold. Being a true Christian does not mean that there exists no place for traditional concepts of death and the afterlife of pre-Christian origin.

The system of beliefs is permanently being reproduced and transferred from one generation to another. A precondition for the persistence of the concepts of afterlife is the stability of culture and society. This was the case also with the Seto society until the rapid changes which started in the 1920s and continued with the destruction of the tradition-based society in the Soviet period. As we saw above, also Mari's concepts of afterlife were multi-layered. Bound with real life, they reflected its changes and contained elements from different temporal strata. Thus, counting the souls might be a reflection of memories of the Estonian army Värska military camp (1926-1940); the idea of the souls of dead women being separated from those of men might recall the deportations $(1941,1949)$ when men were separated from their families; the idea that the dead live in numbered rooms recalls the realities of Soviet times, e.g. hospitals or prison. In some way, the spirit of experienced authoritarian state order could be felt in the images of afterlife.

However, in an unexplained way elements from much earlier times, unavailable for personal memory, could also appear in the perceptions of afterlife. In Mari's case, the image of the dead husband living "as if in a trough" is evidently the reflection of burial in dug-out coffins - a tradition belonging to the old burial practices of the Setos and also other eastern Finno-Ugric peoples (Richter, 1982, p. 98). In spite of Mari's vision, dug-out coffins were not used within her lifetime and she did not remember burying in them. In a similar way, folklore texts about the spirits of the dead appearing in white clothes on old cemetery sites reflect the former practice of burial in white linen clothes - a practice that can be observed in the late medieval and post-medieval archaeological record of southern Estonia.

A look into the tradition-based Seto perception of death and afterlife shows that archaeology, when being limited with tools of the profession, can grasp only a few aspects of former beliefs, just the small tip of the iceberg. Burial archaeology can never catch the full set of ideas bound to the funeral rites and practices. However, it is exactly these beliefs in their whole complexity that have been the background and context for the formation of the archaeological record. Ethnographic and folkloric evidence makes us also bear in mind that the personal factor, including the dreams and supernatural experiences, both of the dead person and of the survivors, should not be underestimated at the formation of the burial record. Maybe just here might be one of the main reasons for its variability.

Archaeology and ethnology have traditionally been regarded as different disciplines, located apart from each other, with different research objects, methods and periods (e.g. Gazin-Schwartz \& Holtorf, 1999, pp. 6-11; Burström, 1999). However, the lack or scantiness of meeting points may be not so much caused by a real separation, but by research traditions. In reality, the connections may be closer than 
suggested, and the archaeological record, giving evidence only of some aspects of the former realities, may be greatly complemented by oral evidence. Oral data may also raise questions about the validity of the existing archaeological interpretations. For example, although the medieval archaeological record from Scandinavian cemeteries since Christianization seems to be clearly of Christian character (e.g. Kieffer-Olsen, 1993), and can be interpreted as a sign of a deeply Christian society, ethnographic data give evidence of numerous popular practices not belonging to the Christian context (Hagberg, 1937). Unfortunately, the possibilities of using folkloric and ethnographic data have largely remained underestimated by archaeologists.

In conclusion, to get a full and adequate basis for archaeological interpretations of historical burial practices in medieval and especially post-medieval Europe, oral, ethnographic and folkloric evidence from the same cultural context should be taken into consideration, where possible and relevant. The smaller the time gap, the more likely is the continuity of tradition and the relevance of the folkloric record. To understand the essence of things, a problem-based approach of multi- or transdisciplinary character might be even more fertile than studies of single aspects of the topic, limited with data possessed by just one speciality.

Cases when the archaeological record has available parallels in ethnological practices and folkloric collections can greatly deepen our understanding of the past. In Estonia, and especially Setomaa, beliefs of a most traditional character have survived up to the 20th century, and the archaeological record from the 13th century until the early 19th century has direct parallels with evidence from folkloric data and within existing practices. Here there is a good chance to look for meanings of the post-medieval and medieval archaeological record more deeply and from other aspects than those enabled by archaeology only. The folkloric data gives archaeology the possibility of seeing the meanings of customs and the multi-dimensionality of beliefs related to death, burials, cemeteries and the afterlife in the context of tradition-based oral culture. In my personal experience, much understanding has been provided by directly encountering some last fragments of the living traditional world view, greatly mediated by Mari.

\subsection{Epilogue: The Departure}

Mari died on May 23, 2003, between Easter and Whitsun, at the age of 91. She was buried in Värska cemetery, according to her will, on the left hand of her first husband - "because woman is made of the left hipbone of man." The morning after her death a cuckoo was calling for a long time on top of the high birch on the border of the household. In local Seto tradition, a cuckcoo coming close to the house is a sign or omen of death. It was sitting on the very top of the tree, on the highest branches which did not bend at all under the weight of the big bird. There had never been a cuckoo so close to Mari's house during my experience. 
Mari was buried with a needle with red yarn, as she had asked, close to her head under the pillow ${ }^{5}$, and a coin by her right elbow. Her headscarf was not knotted under the chin. A diagonal cross of red yarn was made under her head - an ancient practice she considered important but the reasons and meanings of which were unknown to her, as they were to anybody else in the present time (see also Richter, 1998, pp. 9698). As Mari's comb could not be found, her cousin, aged over 80 , gave hers, saying that it must be put into the coffin. During Mari's last stay at home, there was a bottle of vodka with a snifter (a glass) and an open box of chocolates at the coffin. And during the 40 days after her departure there stood a bench, covered with white cloth and with a candle on it, in front of the Holy corner with icons - for the soul to rest.

Mari persuaded me not to kill a chicken for her funeral: "Do what you want with the hen, but I do not want that any chicken should lose its life because of me.” However, when returning from the commemoration marking six months since her death, the car accidentally struck a roe deer on the road. The hunters came in response to a phone call and cut the throat of the mortally-wounded animal. Slaughtering an animal for funerals - a blood sacrifice for the dead - was an obligatory part of traditional Seto burial rites.

\section{References}

Arpo, M. (1996). Noppeid setu vanade matusekommete kohta. In H. Valk \& E. Västrik (Eds.), Palve, vanapatt ja pihlakas. Setomaa 1994. a. kogumisretke tulemusi. (Vanavaravedaja 4) (pp. 241-267). Tartu.

Arukask, M. 2012. Some observations about boundaries in Vepsian folk culture. Finno-Ugric Folklore, Myth and Cultural Identity. Proceedings of the Fifth International Symposium on Finno-Ugric Languages. University of Groningen, June 7-9, 2011, (pp. 9-20). Maastricht: Shaker Verlag.

Burström, M. (1999). Focusing on time: disciplining archaeology in Sweden. In Amy Gazin-Schwartz and Cornelius Holtorf. (Eds.), Archaeology and folklore (pp. 35-47). London, New York: Routledge,

Gazin-Schwartz, A. \& Holtorf, C. (1999). “As long as ever l've known it...”: on folklore and archaeology. In Amy Gazin-Schwartz and Cornelius Holtorf. (Eds.), Archaeology and folklore (pp. 3-25). London, New York: Routledge.

Hagberg, L. (1937). När döden gästar; svenska folkseder och svensk folktro i sambad med död och begravning. Stockholm: Wahlström \& Widstrand.

Hausmann, R. (1903). Ausserkirchliche Begräbnissplätze im Estenlande in christlicher Zeit. Sitzungsberichte der Gelehrten Estnischen Gesellschaft 1902, pp. 134-155.

5 Respecting Mari's wish, we still did it - in spite of the neighbour's words who asked not to give the needle. She told that after adding it into the coffin of her mother, she had appeared in a dream and told likewise being surrounded by needles. I did not follow the advice of another person in the village. He told me that immediately after carrying the coffin out of the house, a nail or any other sharp item, e.g. a thumbtack must be kicked or pressed in the floor in the place where the coffin had stood - otherwise the dead will begin visiting the home as a revenant. 
Jetsu, L. (2001). Kahden maailma välillä. Etnograafinen tutkimus venäjänkarjalaisista hautausrituaaleista 1990-luvulla. Helsinki: Suomalaisen Kirjallisuuden Seura.

Järvinen, I.-R. (2004). Karjalan pyhät kertomukset: tutkimus livvinkielisen alueen legendaperinteestä ja kansanuskon muutoksista. Helsinki: Suomalaisen Kirjallisuuden Seura.

Kieffer-Olsen, J. (1993). Grav og gravskik i det middelalderlige Danmark: 8 kirkegårdsudgravninger. Moesgård: Afd. for Middelalder-Arkaeologi og Middelalder-Arkaeologisk Nyhedsbrev.

Laul, S. \& Valk, H. (2007). Siksälä: a Community at the Frontiers. Iron Age and Medieval. CCC Papers, 10. Tallinn-Tartu.

Loorits, O. (1949). Grundzüge des estnischen Volksglaubens. Skrifter utgivna av kung. Gustav Adolfs Akademien för folklivsforskning, 18 (1). Uppsala, Köpenhamn: Gustav Adolfs Akademien.

LUB Liv-, Ehst- un Curländisches Urkundenbuch, VII (1881). Riga, Moscow.

Manninen, I. (1924). Setude matusekommetest. Eesti Keel 1924, III, 10-19.

Panchenko, А. (1998). Панченко А. А. 1998. Исследования в области народного православия. Деревенские святыни Северо-запада России. С.-Петербург.

Pentikäinen, J. (1971). Marina Takalon uskonto. Helsinki: Suomalaisen Kirjallisuuden Seura.

Piho, M. (2011). Setode usk ja Setomaa tsässonad. In A. Raudoja \& T. Mäkeläinen (Eds.), Setomaa tsässonad. (pp. 13-60). Tartu: Seto Kultuuri Fond.

Richter, J. (1979). Рихтер Е. 1979. Некоторые особенности погребального обряда сету. Советская этнография, (1979), 2, pp. 116-127.

Richter, J. (1982). Mõningaid arhailisi jooni setu matusekommetes. Läänemeresoomlaste etnokultuuri küsimusi.(pp. 96-100). Tallinn.

Setomaa (2014). Setomaa. Unique and genuine. (Helen Külvik, Ed.), Tartu: SA Seto Instituut.

Stark, L. (2002). Peasants, Pilgrims, and Sacred Promises. Ritual and the Supernatural in Orthodox Karelian Folk Religion. Studia Fennica. Folkloristica, 11. Helsinki: Finnish Literature Society.

Torp-Kõivupuu, M. (2003). Surmakultuuri muutumine ajas: ajaloolise Võrumaa matusekombestiku näitel. (Tallinna Pedagoogikaülikooli Toimetised. Humaniora, A22). Põltsamaa: Vali Press.

Valk, H. (1995a). Reflections of folk-religion and beliefs in Estonian burial customs of the 13th-19th centuries. Archaeology, folklore and written sources. In Ingmar Jansson (Ed.), Archaeology East and West of the Baltic. Papers from the Estonian - Swedish Archaeological Symposium, Sigtuna, May 1991. Theses and Papers in Archaeology N.S., A 7. (pp. 131-153). Stockholm.

Valk, H. (1995b). The 13th -17th centuries' South Estonian village gravefields in folk-tradition and beliefs. Folk-Belief Today. (pp. 501-509). Tartu.

Valk, H. (2001). Rural cemeteries of Southern Estonia 1225-1800 AD. $2^{\text {nd }}$ edition. CCC Papers, 3. Visby -Tartu:Centrum för Östersjöstudier.

Valk, H. 2003. Christianisation in Estonia: a Process of Dual-Faith and Syncretism. In M. Carver (Ed.), The Cross goes North. Processes of Conversion in Northern Europe, AD 300-1300 (pp. 571-579). York: York Medieval Press/Boydell Press.

Valk, H. 2006. Burial grounds and related rites in the traditional world-view of the Setos of Southeastern Estonia. In A. Andren \& K. Jennbert (Eds.), Old Norse religion in long-term perspectives. Origins, changes and interactions. Lund, Sweden, June 3-7, 2004 (pp. 141-146). Lund: Nordic Academic Press.

Valk, H. (2009). Hilisrauaaeg (1000/1050-1225). Setomaa, 2. Vanem ajalugu muinasajast kuni 1920. Aastani. (p. 126-174). Tartu: Eesti Rahva Muuseum.

Valk, H. \& Västrik, E. (Eds.) (1996). Palve, vanapatt ja pihlakas. Setomaa 1994. aasta kogumisretke tulemusi. Vanavaravedaja, 4. Tartu. 